\title{
Delay Analysis of Raw Water Reservoir and Pumping Station
}

\author{
Venu Malagavelli, Bala Krishna Chetlapally, Prasad Bollini
}

\begin{abstract}
Inadequate or feeble preliminary work prior beginning of development of any structure may become the root for difficult issues during the development time span. Therefore, the expense of development increments digressively, the development length of the task expands and the standard of development is influenced unfavorably. This examination harps on the significance of development plans in accomplishing the point of creating great quality development work inside the predefined span. Checking constantly the interrelated connection regarding delays in development plans and contractor orders is an entangled procedure. Here the easiest and fundamental methodology is that, both for proprietor and contractor, time is cash and consequently development plan deferrals ought to be broke down and remedial measures ought to be taken in a convenient way. The principle motivation behind this examination is to research the reasons for development plan delays and the techniques for plan delay investigations. In this examination, the completion development works of a "Raw water Reservoir and Raw water Pumping Station" at Bommakal village in Karimnagar District was chosen as a contextual investigation for examining task planning and the delay analysis. The fundamental reason for this examination is to recognize the defer aspects and the impact on the undertaken work fulfillment. This investigation adopts a coordinated strategy and tries to examine the influence of consequence. A survey was led to distinguish the circumstances and end results delay from contractor and customer. From the examination, it is distinguished that the most significant deferrals from a list 20 distinct causes and 4 distinct impacts of postponements and the suggestions to diminish the postponement. The actual arranged schedule is 713 days and updated proposed schedule is 683 days the total delay was 30 days.
\end{abstract}

Keywords: Construction Delays, Construction activities, Project Analysis, Project schedule, Resource analysis.

\section{INTRODUCTION}

The structural administration it might mention to the contractual positioning under which a firm furnishes building

Revised Manuscript Received on February 05, 2020.

* Correspondence Author

Venu Malagavelli*, Department of Civil Engineering, Institute of Aeronautical Engineering, Dundigal, Hyderabad, India.

E-mail: venu.bits@gmail.com

Bala Krishna Chetlapally, Department of Civil Engineering, Institute of Aeronautical Engineering, Dundigal, Hyderabad, India.

E-mail: balakrishnaace@outlook.com

Prasad Bollini, Department of Civil Engineering, CMR College of Engineering and Technology, Kandlakoya, Hyderabad, India.

E-mail: bolliniprasad@gmail.com

(C) The Authors. Published by Blue Eyes Intelligence Engineering and Sciences Publication (BEIESP). This is an open access article under the CC BY-NC-ND license (http://creativecommons.org/licenses/by-nc-nd/4.0/) administration aids to an owner. Anyway, in its progressively regular use it alludes to the act of dealing with the development procedure which is the best approach to deal with the essential asset of development. The asset included workers and subcontractor, appliance and development plant, material, cash and span. Capable structural administration brings about the undertaken work culmination on schedule and inside allotted money. Time optimization is the root for successful work administration. There are a couple of issues that make impact on the time organization, for example, the alteration in work particulars with no straight notice, work burden, nonsensical time curb and so forth. The effect obtained due to inferior time administration may give rise to postponement or terrible result on price as it corresponds to one another. As an answer of this circumstance the arranging and planning would be the most suitable strategy that could be utilized to solve with this issue. With the best possible arranging and planning it will help the venture chief in finishing the task inside the span and fulfill the objective and target of the undertaken work.

\section{DELAY ANALYSIS}

Delay analysis is a well-developed technique to find the delays in the project using Primavera. Delay analysis is used to find the delays and its effects on the project cost and factors affecting the project. The delays analysis also focuses on the precautionary measurement to complete the project within the time. Indian Building industry in the recent times is encountering a numerous issue resulting in the loss of a billion ringgit. The principle factor which produces the unsteadiness to the building profession is price and span. By alluding to the news in broad communications the expense and the span of the undertaken work will be the main constituent that directs to either unfurnished work or late in the completion of the task. This circumstance will make a great deal of issues with the customer which is the customer must do the clearance back to the bank given even though the task remains incomplete. Price of the venture is an aspect which generally directs to the postponed or unfurnished works. Lack of the best possible scheduling in the building industry result in the loss of a number of profits from various tasks and this circumstance becomes the root for non-completion of the project within the span. The foundation venture is the work that includes a great deal of cash and utilizing a ton of time to be finished. The building industry must plan the work price which shall be beneficial in the coming times as the organization must anticipate the materials cost for the coming up times if any state arises that might steer to the expansion of the materials cost.

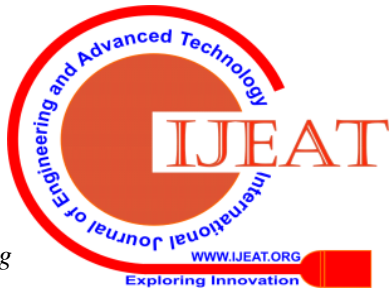




\section{Delay Analysis of Raw Water Reservoir and Pumping Station}

The unmanageable utilization of the resources in the field work additionally becomes the aspect which directs to the loss of numerous benefits. The reason for this is that if the building industry did not properly govern the utility of the resources, this would lead the industry to expend a lot of amount not considering the scheduling price and when the time of completion arrives, the industry will lose a great deal of cash and often the industry will endure the loss of benefits in the tasks. Additionally, the time planning arises as the main consideration the steers to the postponed or the unfurnished tasks. The building industry is confronting an intense test in the time scheduling of the work on the grounds that with deficit organization of the time aspect will make the loss of benefits to the industry. The entirety of the development organization have arranging and planning the time initially prior beginning the work and a portion of the organization didn't pursue good the time requirement of the task and this circumstance will direct to the deferred tasks. Some of the times the building organizations that are arranging their time for the works do not focus about the natural aspects while doing the arrangement. Natural aspects must be taken into consideration while making plans for the arrangements as the adverse effects of the natural aspects to the organization of the tasks would lead to the deferred tasks and simultaneously leads to the loss of benefit to the organization. Hence it becomes imperative to convey an investigation on plan development of a work.

The investigation focuses on the task succession, arranging and planning procedures which are utilized in the whole work. This investigation harps on the significance of development plans in accomplishing the point of delivering great quality development work inside the predetermined span. Checking constantly the interrelated connection focusing detains in building timetables and contractor commands is a tangled procedure. Here the least difficult and fundamental methodology is that, both for owner and contractor, time is cash and hence development plan postponements shall be studied and remedial measures ought to be taken in an opportune way.

Arıkan and Dikmen (2004) presented the meaning of arranging as "Attempting to envision what will occur and concocting methods for accomplishing the arrangement of goals and targets", and figure out that in arranging idea there are consistently destinations to be accomplished in the coming times. The creators depict arranging as "a procedure during which endeavors and choices are made to accomplish the objectives at the ideal time in the ideal way".

Mubarak (2005) presents that task arranging works for various aspects, example, cost assessing, booking, work command, wellbeing of the administration, and so on. As indicated by Arıkan and Dikmen (2004) the principle reason for arranging is to give the essential obligations of the chief, in particular, course and control. The second goal of arranging is to sort out every connections and data frameworks among the numerous gatherings engaged with the development works.

Smith (2002) stresses the significance of cautious and constant work arrangeent in the accomplishment of an acknowledgment of a project; and furthermore takes note of that the exercises of planners, makers, providers, laborers and contractors, and their assets must be facilitated and coordinated with the goals of contractor.

Oberlender (2000) concurs with Smith that arranging facilitates all the tasks of the development to arrive at a finished quality work. The creator decides the fundamental advantage of task arranging and planning as a viable device of anticipating a portion of the issues like deferrals in work, over price or decreases in efficiency and basically puts

- Complete the work on schedule.

- Uninterrupted flow of tasks (no delays).

- Declined measure of improvement (least measure of alterations).

- Reduce perplexity and mistaken assumptions.

- Inflated information on status of work by everybody.

- Consequential and timely status to the board.

- You compete the undertaking rather than the work competing you.

- Information on planned times of key aspects of the task.

- Information on dispersion of expenses of the work.

- Accountability of individuals, characterized obligation/authority.

- Evident comprehension of who does what, when, and how much.

- Integration of all work to guarantee a quality task for the owner.

Trauner et al., (2009) clarify the fundamental reasons for a project plan as adequately delineating the development plan to the task members, allowing the board to control what's more, measure the movement of the work, lastly assiting the members with data for opportune choices.

Callahan et al., (1992) profess that the expectations of on-schedule, on-budget, and debate free culmination might be expanded by means of a timetable and the reason for the timetables is indicated by the individual utilizing the timetable. The creators further disclose that the reason to anticipate work fulfillment for contractor is that they could set out team sizes, duties or tools to quick or unhurried advancement.

Callahan et al., (1992) likewise demonstrate that timetables are utilized for estimating deferrals and time expansions. If the timetables are routinely refreshed including work arrangements, unforeseen postponements, original action fulfillment dates and altered orders, then the owner and contractor can gauge the effect of extra tasks and unexpected deferrals, hence evading arguments.

Abd El-Razek et al., (2008) contemplated a few articles on analyzing the reasons for building development delays from numerous points of view; a few investigations evaluated the primary aspect of deferral in various nations. The authors have listed 87 causes of construction delays. In the examination embraced by Assaf et al., (1995) the biggest number of reasons for deferrals (56 causes) was recorded and the respondents were solicited to point attention to their degree of significance. The creators assembled the postpone factors into nine significant gatherings: financing, materials, legally binding connections, work alterations, government relations, labor, planning and control, tools, and ecological elements.

Lo et al. (2006) studied the aspects of development delays in Hong Kong structural designing activities, was managed predominantly incorporating the view of civil building professionals on how significant are the reasons for delays as appeared in the Table I. 
The Primavera software is a significant source in directing this investigation. This software will be utilized to build up a arranging and planning model for the reservoir and pumping station erection work. This investigation additionally will focus on a contracting organization which is engaged with the erection work of reservoir and pumping station at Bomakkal village in Karimnagar (District).

Table- I: Causes of delays in construction (Lo et al., 2006)

\begin{tabular}{|c|c|c|}
\hline Researchers & Country & Major causes of delay \\
\hline $\begin{array}{c}\text { Arditiet al., } \\
\text { (1985) }\end{array}$ & Turkey & $\begin{array}{l}\text { Lack of assets, Money } \\
\text { related challenges looked } \\
\text { by public, organizations } \\
\text { and contractors, } \\
\text { Organizational deficits, } \\
\text { Deferral in configuration } \\
\text { of tasks }\end{array}$ \\
\hline $\begin{array}{c}\text { Mansfield et } \\
\text { al., (1994) }\end{array}$ & Nigeria & $\begin{array}{l}\text { Inappropriate budgetary } \\
\text { and expend courses of } \\
\text { action, Poor agreement of } \\
\text { organization, Deficiency } \\
\text { of materials, Wrong cost } \\
\text { appraisals }\end{array}$ \\
\hline $\begin{array}{c}\text { Assafet } \\
\text { al.,(1995) }\end{array}$ & $\begin{array}{l}\text { Saudi } \\
\text { Arabia }\end{array}$ & $\begin{array}{l}\text { Slow arrangement and } \\
\text { endorsement of shop } \\
\text { drawings, Postponement } \\
\text { in installments to } \\
\text { contractor, Alterations of } \\
\text { structural design }\end{array}$ \\
\hline $\begin{array}{l}\text { Ogunlanaet } \\
\text { al.,(1996) }\end{array}$ & Thailand & $\begin{array}{l}\text { Lack of materials, } \\
\text { Alterations of structural } \\
\text { design, Contact issues } \\
\text { among the contracting } \\
\text { parties }\end{array}$ \\
\hline $\begin{array}{c}\text { Chan and } \\
\text { Kumaraswamy } \\
\text { (1996) }\end{array}$ & $\begin{array}{l}\text { Hong } \\
\text { Kong }\end{array}$ & $\begin{array}{l}\text { Unexpected ground states, } \\
\text { Lack of site } \\
\text { administration and control } \\
\text { Slow conclusion making } \\
\text { by work groups }\end{array}$ \\
\hline
\end{tabular}

\section{ANALYSIS OF DATA}

The project "Raw water Reservoir and Raw water Pumping Station" is located at Bomakkal village in Karimnagar (District). This project is constructed under Godavari Drinking Water Supply Project Pase-1 and named as Maulana Abdul Kalam Hyderabad Srujala Sravanthi Scheme.

This project is constructed by Nagarjuna Construction Company Limited.

Name of the project : Raw water Reservoir and Raw water Pumping station

Built up area $\quad$ : 18420.86 Sqm

Total Project Duration: 24 Months

Cost of the project $\quad: 15.84$ Crores

Hyderabad Metropolitan Water Supply and Sewerage Board and AP Transco officials are at loggerheads over independent power lines for the project. The drinking water work expects to bring 172 Million Gallons every day (MGD) from the Yellampally barrage in Karimnagar to fulfill water need. The scheme, envisaged to bring 10 TMC water from river Godavari to Hyderabad city. The total project cost Rs. 3375 crores are estimated.

\section{METHODOLOGY}

The following methodology has been adopted for the delay analysis of the project.

\section{A. Data Analysis of Study}

Effects of development plan deferrals on the span of the contextual analysis of the work were examined by the assistance plan arranged in Primavera. The aftereffects of use of the choose strategy and the discourses are given in this segment under separate headings, explained with figures and tables. When the task is planned, the action subtleties are acquired in a bar diagram view. The similar type can likewise be seen in a PERT view. These perspectives show the action subtleties which incorporate action names, term, quick start and completion times, and so on in the information sections zone. It very well may be seen that once the planning happens, the actions are consequently set out in the order for quick start times and are recorded in a similar pattern in the information section of the P6 screen. There are a sum of 20 significant actions associated with this present task. The action names initiate from field clearing work and stretch out till the last floor slab, casing the whole work of the structure inclusive of the insides. The whole number of working days to finish the task adds up to 713 days. This task focuses to get the critical exercises in the work plan.

\section{B. Analysis of Activities}

As mentioned above, the project starts with the activity of site clearing work. To efficiently manage labor, time and resources, the construction of the building is divided into three work packages. The packages are named as Preconstruction, Construction \& Post Construction. The activity names of the segments are succeeded by the respective segment number. The durations for each segment can be inferred from the data column box of the activity. All the activities entered may have one or more successors and have none or one and more than one predecessors. The distinction between most recent beginning time and the soonest start time of an action is called variously as float, total float or activity slack.

Float is a proportion of measure of time by which the beginning of an action can be deferred predictable with the fulfillment of the task on schedule. In order that any property of an activity has to be changed after the scheduling is done, it can be done so in many ways. One of the easier methods is by double clicking on the activity name, where activity detail dialog box appears. All the properties of the activities can be reviewed, altered depending upon the requirement. All the properties of the selected activity appear in this dialog box. The materials and equipment required to complete an activity is assumed to be readily available at all times such that it has no effect on the durations of the activity. The labor force is also increased at some stages to maintain the duration of the activities so that critical activities are unaffected.

\section{Impacted As-Planned Method}

Different names of this technique are "what-if" or "adjusted baseline" strategy. In this technique the as-arranged timetable 


\section{Delay Analysis of Raw Water Reservoir and Pumping Station}

And additions into this timetable produce alterations which directs to deferral works. These alterations are the main decided deferrals registered during development procedure which might have influenced the term of the work. The span between the fulfillment date showed on the as-arranged program and the one on the affected as-arranged program is considered as postponement to which a contractor is qualified for an augmentation of time as a methods for a reasonable deferral action.

\section{Project Schedule}

The total project duration was 713 days (includes inception stage to completion stages). The original arranged timetable comprises various kinds of exercises with various spans dependent on their inclination of work. The actual planned schedule also contains the WBS (Work Breakdown Structure) where the activities are categorized under their specific work. The actual planned schedule also explains about the resources and roles which are assigned to the activities according to the work. The planned schedule helps us to find the status of the work and what are the next activities to be done with required resources and roles without any delays.

The updated proposed schedule duration was 683 days. The updated proposed schedule is prepared by an general survey conducted regarding the duration of the project. The survey is conducted to find whether the planned schedule can be reduced by adding more resources (manpower, equipment) such that the schedule is decreased by 30days. The updated proposed schedule the duration is decreased by assigning more resources but the cost of the project increases.

The duration analysis is to compare the actual planned schedule duration and updated proposed schedule. The duration of the activities are taken into account to show the difference between the actual planned schedules and updated proposed schedule. The duration of the activities are compared to find the delays in both the schedules. The durations of the two schedules are shown in Fig.1 and 2.

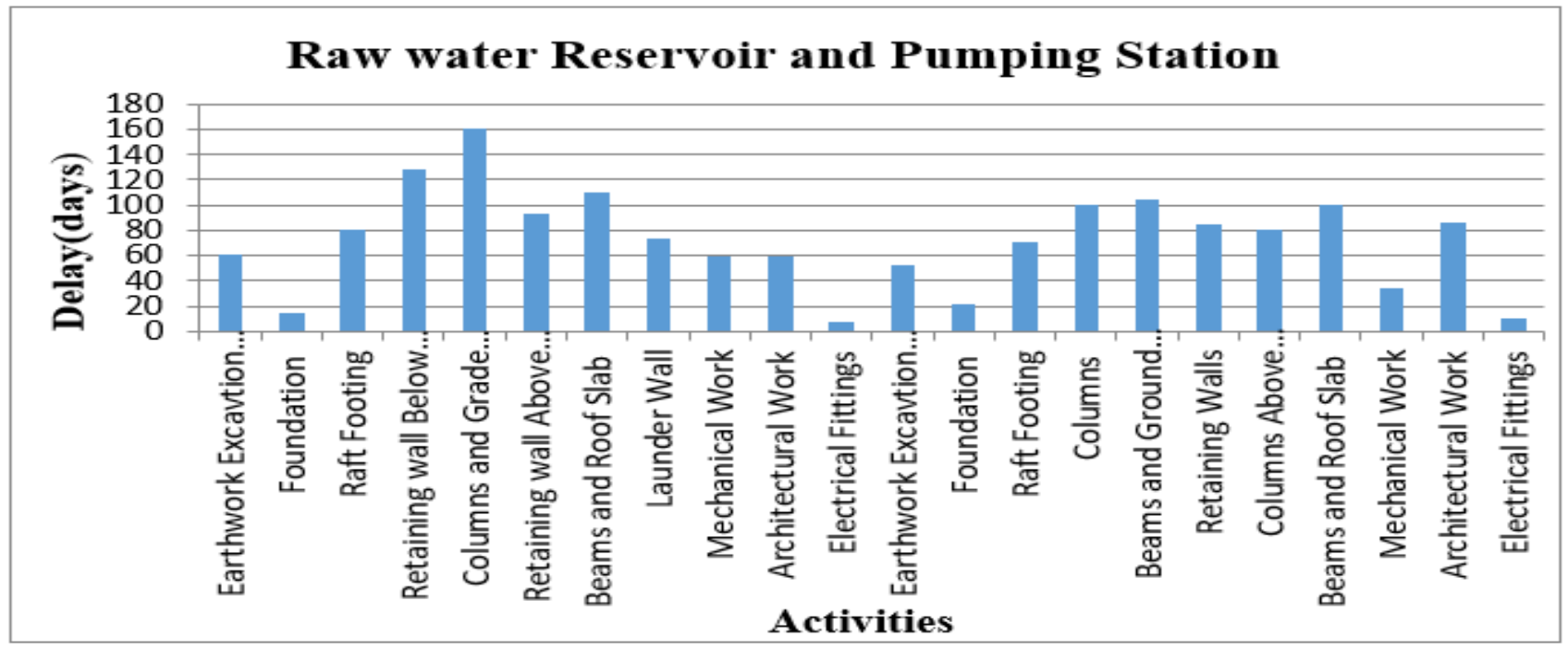

Fig.1 Duration of actual planned schedule

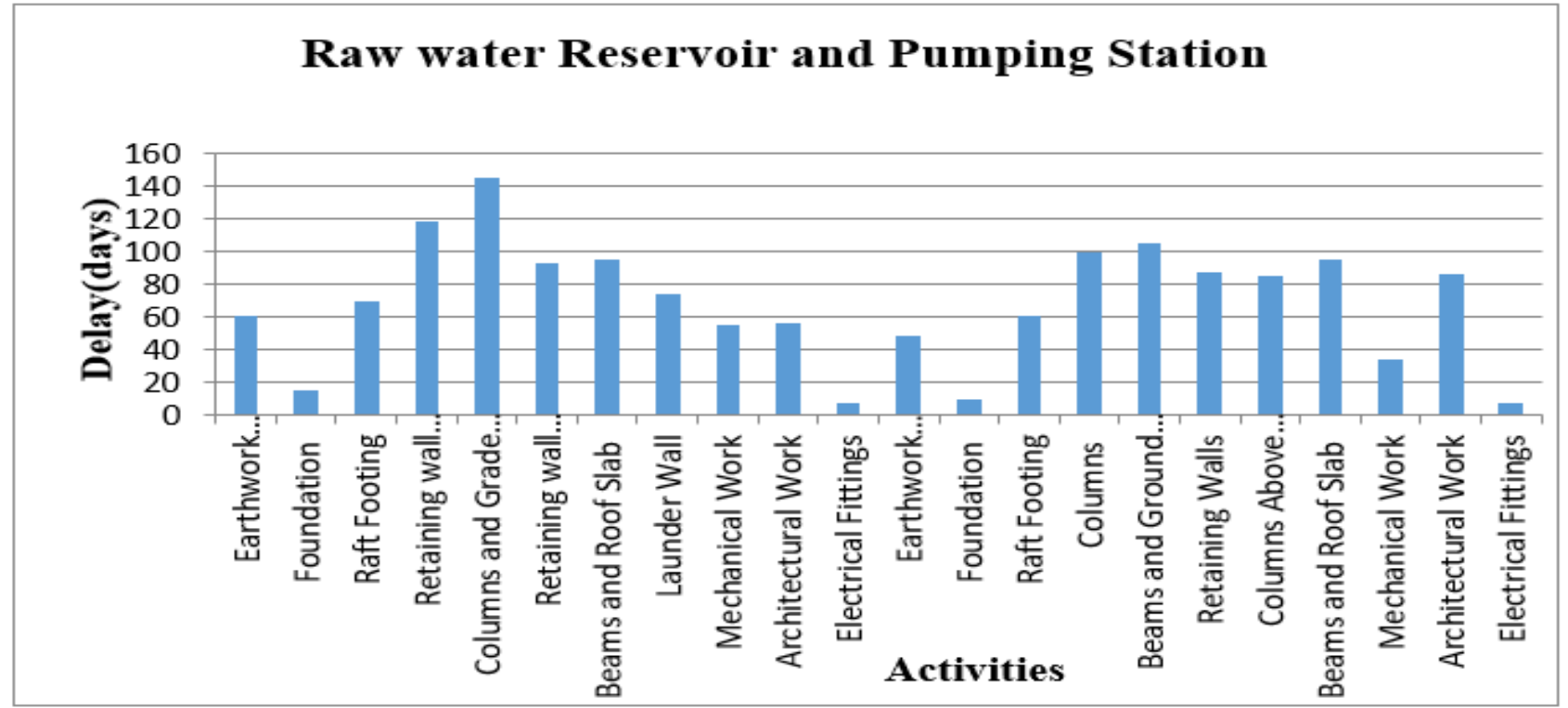

Fig.2 Duration of updated proposed schedule 


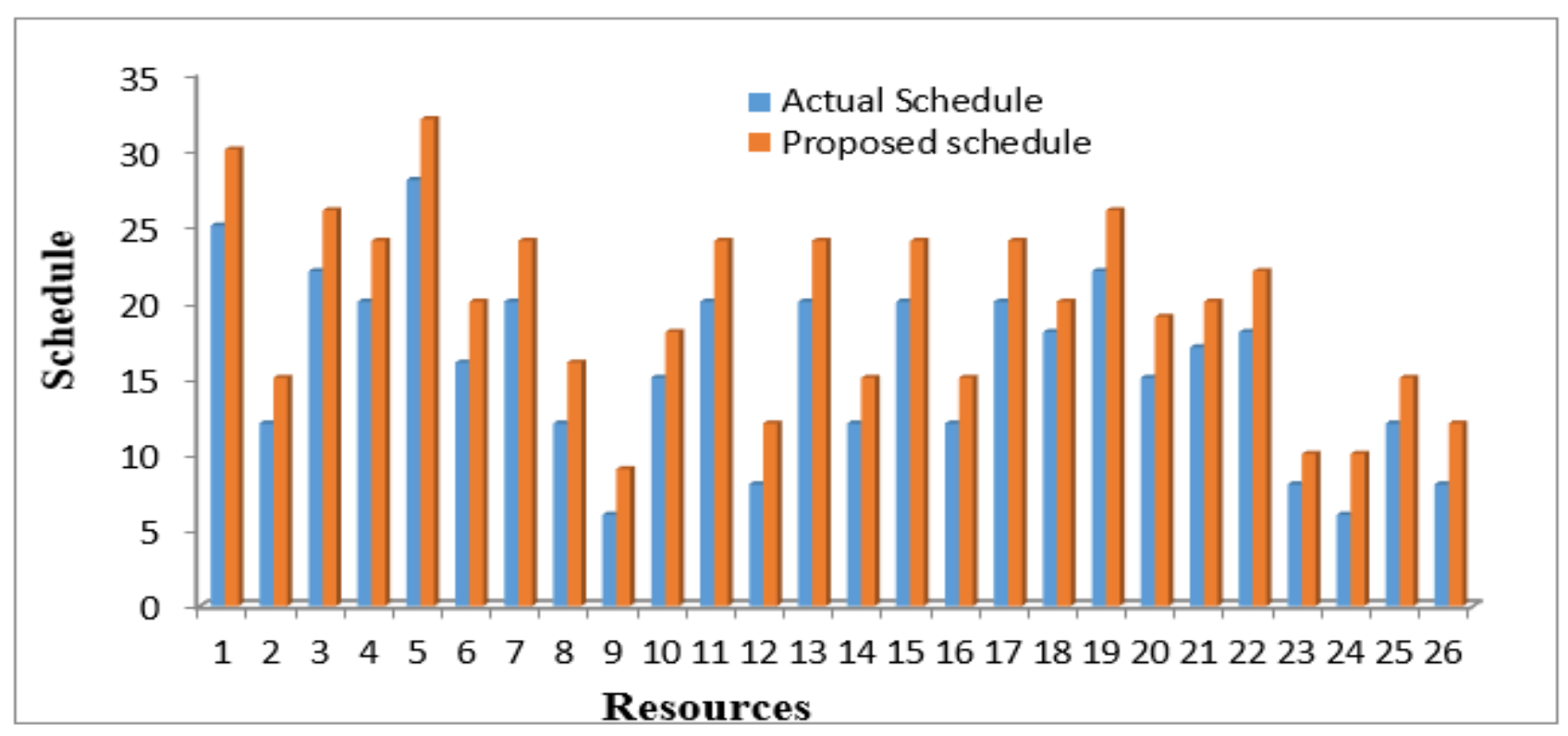

Fig.3 Resources Analysis of Actual Planned Schedule and Updated Proposed Schedule

The above Fig.1 explains about the duration of actual planned schedule of the activities. The duration of the project for planned schedule is 713 days. The above Fig.2 explains about the duration of updated proposed schedule of the activities. The duration of the project for updated is 683 days.

\section{E. Resources Analysis}

The Resources analysis is to compare the actual planned schedule duration and updated proposed schedule. The resources used in the project are taken into the account to show the difference between the two schedules for completion of the project. The resources for two schedules are show in Figure 3.

The Fig. 3 shows the resources allocated for the two schedules and the resources assigned for the actual planned schedule takes the project to complete in 713 days and the resources for updated proposed schedule takes 683 days. For updated proposed schedule the resources are assigned more and made the activities not to delay. By assigning more resources the schedule is reduced by 30 days and the effects of delays are reduced.

\section{RESUlTS AND DiscuSSION}

For this study work, there were an aggregate of 20 cases deferred occasions including both critical and non-critical deferrals. 11 of them are happened in critical activities whereas 9 of them happened in non-critical activities. The critical activities are appeared in Table II.

Table-II: Causes and Types of Delays

\begin{tabular}{|l|l|l|l|}
\hline S.No & Delay Description & $\begin{array}{l}\text { Impacted Activity Name } \\
\text { (IAN) }\end{array}$ & $\begin{array}{l}\text { Impacted Activity } \\
\text { Code (IAC) }\end{array}$ \\
\hline 1 & Delay occurred due to unforeseeable weather condition & Earthwork excavation & P 1040 \\
\hline 2 & $\begin{array}{l}\text { Delay in supply of steel for Raft Footing Reinforcement } \\
\text { occurred due to transportation }\end{array}$ & $\begin{array}{l}\text { Raft Footing/ } \\
\text { Reinforcement }\end{array}$ & P 1110 \\
\hline 3 & $\begin{array}{l}\text { Delay in Reinforcement of Retaining wall occurred due to } \\
\text { corrections in drawing }\end{array}$ & Retaining walls & P 1170 \\
\hline 4 & $\begin{array}{l}\text { Delay in backfilling compaction for Retaining wall due to } \\
\text { failure of equipment while the work was in progress }\end{array}$ & Backfilling compaction & P 1240 \\
\hline 5 & $\begin{array}{l}\text { Delay in cut and bend of steel in Columns and Grade slab } \\
\text { Reinforcement }\end{array}$ & Columns and Grade slab & P 1250 \\
\hline 6 & \begin{tabular}{l} 
Delay in formwork for Columns and Grade slab \\
\hline
\end{tabular} & Columns and Grade slab & P 1270 \\
\hline
\end{tabular}


Delay Analysis of Raw Water Reservoir and Pumping Station

\begin{tabular}{|l|l|l|l|}
\hline 7 & $\begin{array}{l}\text { Delay in Earthwork excavation occurred due to } \\
\text { predecessor activity }\end{array}$ & Excavation & P 1770 \\
\hline 8 & $\begin{array}{l}\text { Delay in compaction of CNS soils occurred due to } \\
\text { unforeseeable weather conditions }\end{array}$ & CNS soils compaction & P 1800 \\
\hline 9 & $\begin{array}{l}\text { Delay in PCC compaction occurred due to equipment } \\
\text { failure }\end{array}$ & PCC compaction & P 1820 \\
\hline 10 & $\begin{array}{l}\text { Delay in marking for Raft footing occurred due to } \\
\text { correction in drawings }\end{array}$ & Raft footing marking & P 1830 \\
\hline 11 & $\begin{array}{l}\text { Delay in supply of steel for Raft footing occurred due to } \\
\text { transportation }\end{array}$ & Raft footing Reinforcement & P 1840 \\
\hline
\end{tabular}

Table-III: Delay in Earth work excavation

\begin{tabular}{|l|l|}
\hline Impacted Activity & Earthwork Excavation \\
\hline Start & $01-04-2013$ \\
\hline Finish & $10-06-2013$ \\
\hline Duration & 61 days \\
\hline Delay Type & Excusable delay \\
\hline Delay Description & Delay occurred due to unforeseeable weather conditions \\
& \\
\hline
\end{tabular}

Table-IV: Delay in Raft Footing Reinforcement

\begin{tabular}{|l|l|}
\hline Impacted Activity & Raft Footing Reinforcement \\
\hline Start & $28-06-2013$ \\
\hline Finish & $09-07-2013$ \\
\hline Duration & 10 days \\
\hline Delay Type & Non-Excusable delay \\
\hline Delay Description & Delay in supply due to transportation \\
\hline
\end{tabular}

Table-V: Delay in Raft Footing Marking

\begin{tabular}{|l|l|}
\hline Impacted Activity & Raft Footing Marking \\
\hline Start & $26-08-2013$ \\
\hline Finish & $11-09-2013$ \\
\hline Duration & 18 days \\
\hline Delay Type & Non-Excusable \\
\hline Delay Description & $\begin{array}{l}\text { Delay in marking for Raft Footing occurred due to corrections } \\
\text { in drawings }\end{array}$ \\
\hline
\end{tabular}

The different delay types, duration of impacted activities and delay descriptions are shown in the Table III to V. The purpose behind choosing Delay Analysis that it can show the advancement of development works bit by bit with the assistance of Primavera programming. The principle benefit of this examination is that the circumstance of development on the refreshed dates could be envisioned neatly. The need for the defer investigation is to reflect the original procedure of development so as to arrive at a precise arranged timetable separately to watch the progressions of the works.

These postponements were delay in detailed drawings, insufficient knowledge of the sub- contractor, issues in material acquisition, unpredictable climate aspects, absence of exact arranging and planning. The postpone investigation is the most practical and the best procedure for deciding the measure of time expansion brought about by development plan delays.

\section{CONCLUSION}

Based on the results, the following conclusions have been drawn.

- $\quad$ It is seen from delay examination that, the total 20 parameters were recognized and studied.

- $\quad$ From the Table II it is indicated that out of these 20 parameters, 11 are the sensitive parameters that effect the overall duration of the construction project.

- It is observed that the updated proposed schedule decreased, by increasing the resources and the cost of the project is also increased.

- From the Fig. 3 it is shown that the updated proposed schedule of the complete project was reduced to 30 days. 
- The choice of the contractor ought to be done through a pre-capability of the firms.

- The contractor should utilize qualified work groups and in-house laborer training so as to upgrade administrative and specialized abilities.

\section{REFERENCES}

1. Arıkan, $M$ and Dikmen, I., "Construction Engineering and Management", 2004, McGraw-Hill, USA.

2. Arditi, R.D. Akan, G.T and Gurdamar, S., "Reasons for Delays in Public Projects in Turkey." J. of Construction Management and Economics, Vol. 3 (3), 1985, pp. 171-181.

3. Assaf, S.A. and Al-Hejji, S.A., "Causes of Delay in Large Construction Project.” Intl. J. of Project Management, Vol. 24, 2006, pp. 349-357.

4. Chan, D.W.M and Kumaraswamy, M.M., "A comparative study of causesoftime overruns in Hong Kong construction projects.” Intl. J. of Project Management, Vol. 15 (1), 1997, pp. 55-63.

5. Oberlender, G.D., "Project Management for Engineering and Construction", 2000, McGraw-Hill, Singapore.

6. Trauner, T.J. Manginelli, W.A. Lowe, J.S. M. F. Nagata and B. J. Furniss, "Construction Delays: Understanding Them Clearly, Analyzing Them Correctly”, 2009, Elsevier Inc., USA.

7. Abd El-Razek, M. E., H. A. Bassioni, and A. M. Mobarak, "Causes of Delay in Building Construction Projects", J. of Construction Engineering and Management, Vol. 134 (11), 2008, pp.831-841.

8. Lo, T.Y. Fung, I.W.H and Tung, K.C.F., "Construction Delays in Hong Kong Civil Engineering Projects." J. of Construction Engineering and Management, Vol. 132 (6), 2006, pp. 636-649.

9. Mansfield, N.R. Ugwu, O.O and Doran, T., "Causes of delay andcost overruns in Nigerian construction projects."'International Journal of Project Management, Vol. 12(4), 1994, pp. 254-260.

10. Mubarak, S., "Construction Project Scheduling and Control", 2005, Pearson Prentice Hall, USA.

11. Smith, N. J., "Engineering Project Management", 2002, Blackwell Science Publishing, USA.

12. Ogunlana, S.O. and Promkuntong, K., "Construction delay in a fast growing economy: comparing Thailand with other economies." Intl. J. of Project Management, Vol. 14 (1), 1996, pp. 37-45

\section{AUTHORS PROFILE}

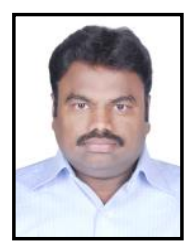

Venu Malagavelli, working as Professor in the Department of Civil Engineering, Institute of Aeronautical Engineering, Dundigal, Hyderabad. He obtained $\mathrm{PhD}$ and ME from BITS Pilani and B.Tech from JNTUCEH, Hyderabad. He published more than 30 papers in International and national Journals and conferences. His area of research is development of new concrete using industrial waste materials. He is a life member of IEI, ICI, IIBE, ISTE etc. He received travel grants from DST and CICS.

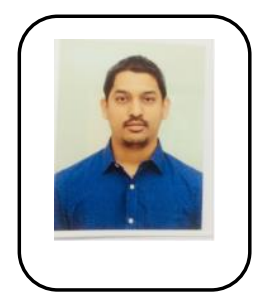

Balakrishna Chetlapally, working as Assistant Professor in the Department of Civil Engineering, Institute of Aeronautical Engineering, Dundigal, Hyderabad. He obtained M.E from University College of Engineering, O.U and B. Tech from Malla Reddy Engineering College, Hyderabad. His area of research is on Disaster Management Mitigation in local bodies - Rural and Urban. He is a life member of ISRD, ISTE, IAENG, IRED.

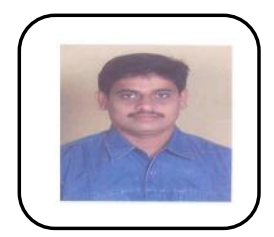

Prasad Bollinii, working as Professor in the Department of Civil Engineering, CMR College of Engineering and Technology, Kandlakoya, Hyderabad. He obtained $\mathrm{PhD}$ from Osmania University and MTech from JNTUH and B.Tech from SV University. He published more than 10 papers in International and national Journals and conferences. His area of research is transportation materials characterization, traffic volume studies, traffic forecasting studies. He is a life member of IEI, ISTE, IAENG, IRED etc. 